\title{
Kemampuan proses matematis siswa Kalimantan Timur dalam menyelesaikan soal matematika model PISA
}

\author{
Anwaril Hamidy ${ }^{1}$, , Jailani Jailani ${ }^{2}$ \\ ${ }^{1}$ Institut Agama Islam Negeri Samarinda. Jalan H.A.M Rifaddin, Loa Janan Ilir, Samarinda, Indonesia. \\ ${ }^{2}$ Universitas Negeri Yogyakarta. Jalan Colombo No. 1, Yogyakarta 55281, Indonesia. \\ E-mail: anwarilhamidyiainsmd@gmail.com \\ * Corresponding Author
}

\section{ARTICLE INFO}

\section{Article history}

Received: 14 August 2019;

Revised: 5 Dec. 2019;

Accepted: 19 Dec. 2019

\section{Keywords}

kemampuan proses matematis; soal matematika model PISA; students' mathematical process; PISA-like mathematics

\section{ABSTRACT}

Penelitian ini bertujuan untuk mendeskripsikan kemampuan proses matematis siswa Kalimantan Timur dalam menyelesaikan soal matematika model PISA. Penelitian ini dilakukan terhadap 300 siswa kelas IX SMP Kalimantan Timur yang belum pernah mewakili Indonesia sebagai sampel PISA bidang Matematika. Siswa tersebut tersebar dari tiga level sekolah (rendah, sedang, tinggi) yang ditentukan berdasarkan hasil Ujian Nasional 2016 pada mata pelajaran matematika. Pengumpulan data menggunakan 16 butir soal matematika model PISA $(\alpha=0,835)$ yang mencakup tiga proses matematis: formulate, employ dan interpret. Kemampuan siswa dianalisis berdasarkan mean measure logit dan selanjutnya ditransformasi ke skala dan level kemampuan matematika PISA, sehingga dapat dibandingkan dengan rata-rata kemampuan siswa Indonesia dan negara OECD dalam studi PISA. Hasil analisis data menunjukkan bahwa kemampuan siswa Kalimantan Timur berada di bawah rata-rata negara OECD. Namun hasil tersebut lebih baik dibandingkan capaian skor siswa Indonesia yang menjadi sampel pada PISA 2015. Berdasarkan kemampuan dalam proses matematis, kemampuan siswa dari level tinggi ke rendah berturut-turut adalah formulate, employ dan interpret. Selain itu, kemampuan proses formulate siswa Kalimantan Timur dari sekolah kategori tinggi di atas rata-rata negara OECD.

This study was aimed to describes East Kalimantan students' mathematical processes proficiency in solving a PISA-like mathematics test. The study was carried out with 300 East Kalimantan ninth-grade students who haven't represented Indonesia as Mathematics PISA samples. The students were spread across three school levels (low, medium, high) determined based on the results of the 2016 National Examination in mathematics. Data collection uses 16 items of PISA-like mathematics test $(\alpha=0.835)$ which includes three mathematical processes: formulate, employ, and interpret. Student proficiency was analyzed based on mean measure logit and subsequently transformed to the scale and level of PISA mathematics proficiency so that it can be compared with the average proficiency of Indonesian students and OECD countries in the PISA study. The results of the data analysis show that the average proficiency of East Kalimantan students is below the average of OECD countries. However, these results are better than the average score of Indonesian students who were sampled at PISA 2015. Based on proficiency in the mathematical process, the proficiency of students from high to low levels consecutively namely: formulate, employ, and interpret. In addition, proficiency in the formulating of East Kalimantan students from high-level schools is above the average of OECD countries.

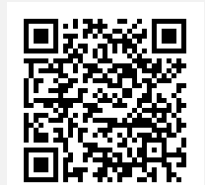

How to Cite: Hamidy, A., \& Jailani, J. (2019). Kemampuan proses matematis siswa Kalimantan Timur dalam menyelesaikan soal matematika model PISA. Jurnal Riset Pendidikan Matematika, 6(2), $133-149$. doi:https://doi.org/10.21831/jrpm.v6i2.26679 


\title{
Jurnal Riset Pendidikan Matematika, 6 (2), 2019 - 134
}

\author{
Anwaril Hamidy, Jailani Jailani
}

\section{PENDAHULUAN}

Matematika merupakan komponen penting pendidikan dalam rangka mempersiapkan siswa menghadapi tantangan di abad 21. Organisation for Economic Co-operation and Development (2013, p. 24) menjelaskan bahwa matematika merupakan alat yang penting bagi remaja dalam menghadapi isu dan permasalahan baik dalam lingkup pribadi, pekerjaan, masyarakat, maupun ilmiah di kehidupan sehari-hari mereka. Hal ini sejalan dengan visi matematika sekolah yang dikembangkan (National Council of Teacher Mathematics, 2000, p. 5) bahwa "in this changing world, those who understand and can do mathematics will have significantly enhanced opportunities and options for shaping their futures. Mathematical competence opens doors to productive futures. A lack of mathematical competence keeps those doors closed."

Dokumen dan kurikulum pendidikan di hampir seluruh negara menunjukkan bahwa salah satu tujuan utama dari pendidikan matematika adalah membentuk kompetensi siswa yang mampu menyelesaikan permasalahan dalam kehidupan sehari-hari (Van Dooren et al., 2011, p. 47). Begitu pula di Indonesia, kompetensi siswa yang dirumuskan dalam Kurikulum Berbasis Kompetensi (KBK), Kurikulum Tingkat Satuan Pendidikan (KTSP) maupun Kurikulum 2013, menunjukkan bahwa kemampuan siswa dalam menerapkan matematika dalam kehidupan sehari-hari merupakan tujuan utama dari pendidikan matematika. Kompetensi matematika sebagai alat dalam menyelesaikan permasalahan di kehidupan sehari-hari juga menjadi perhatian dalam penelitian Programme for International Student Assessment (PISA).

Pusztai dan Bacskai (2015, p. 146) menjelaskan bahwa PISA bertujuan untuk menilai kompetensi siswa dalam menerapkan pengetahuan dan keterampilan mereka pada konteks dunia kerja dan menyajikan hasilnya dalam bentuk yang dapat dikomparasikan dengan negara-negara lainnya. Wijaya et al. (2014, p. 556) menjelaskan bahwa tujuan PISA beririsan dengan tujuan pembelajaran matematika, yakni memberikan gambaran tentang kemampuan siswa dalam menerapkan matematika dalam berbagai situasi. Dengan demikian, penelitian PISA dalam konteks kemampuan matematika bertujuan memprediksi kemampuan siswa untuk menerapkan konsep-konsep matematika dalam menyelesaikan permasalahan di dalam kehidupan sehari-hari.

Kemampuan matematika siswa dalam penelitian PISA dikenal dengan istilah literasi matematika. (Organisation for Economic Co-operation and Development, 2013) mendefinisikan literasi matematika sebagai suatu kemampuan dalam merumuskan permasalahan sehari-hari pada berbagai konteks (pribadi, pekerjaan, sosial, keilmuan) ke dalam berbagai bentuk matematika, lalu mengolahnya dengan berbagai bidang matematika (data dan peluang, ruang dan bentuk, kuantitas, perubahan dan hubungannya) sehingga diperoleh penyelesaian dari permasalahan kontekstual tersebut. Konsep literacy tersebut menitikberatkan kepada kemampuan anak dalam menerapkan pengetahuan dan keterampilan matematika serta kemampuan menganalisa, menalar, dan berkomunikasi (seperti mengajukan, menyelesaikan, dan menginterpretasikan permasalahan) secara efektif pada situasi yang beragam dalam kehidupan.

Konsep literasi matematika kaitannya dengan kemampuan menyelesaikan permasalahan matematika dalam kehidupan sehari-hari dijelaskan dalam domain proses matematis. Domain proses mendeskripsikan bagaimana individu menghubungkan suatu masalah dengan konsep matematika sehingga dapat menyelesaikan masalah tersebut (Stacey, 2011, p. 103). Artinya, domain proses mendeskripsikan tentang kemampuan proses matematisasi siswa terhadap permasalahan kehidupan sehari-hari. de Lange (2006, pp. 18-19) menjelaskan proses matematisasi menjadi lima tahapan: (1) diawali dengan adanya suatu permasalahan yang berkaitan dengan dunia nyata; (2) selanjutnya mengidentifikasi ide matematika yang relevan dan mengatur kembali permasalahan tersebut berdasarkan ide matematika yang teridentifikasi; (3) penyesuaian model matematika sehingga dapat diselesaikan; (4) menyelesaikan permasalahan yang telah berupa model matematika; (5) memberikan pemaknaan dari solusi matematika dalam konteks kehidupan nyata.

Neumann et al. (2013, p. 82) berpendapat bahwa proses matematisasi sepadan dengan pemodelan matematika (mathematical modeling). Blum (2011, pp. 17-18) menjelaskan bahwa proses pemodelan matematika melalui tujuh tahapan. Pertama, memahami ciri-ciri dari permasalahan dan mengasumsikan berdasarkan konteks dan pengalaman. Kedua, simplifikasi: yakni menemukan struktur utama dari permasalahan. Ketiga, matematisasi: yakni mentranslasikan permasalahan dunia nyata ke dunia matematika. Tahapan ini dilakukan dengan mendeteksi ciri-ciri permasalahan dunia nyata yang berkorespondensi dengan konsep matematika. Keempat, menyelesaikan permasalahan dengan konsep, algoritma, 
atau rumus matematika tertentu. Kelima, menginterpretasikan dan mengevaluasi penyelesaian matematika ke dalam dunia nyata. Keenam, melakukan validasi bahwa model matematika yang digunakan konsisten dan sesuai dengan konteks dunia nyata. Ketujuh, mengkomunikasikan penyelesaian beserta argumentasinya.

Domain proses matematis pada konsep literasi matematika sendiri mencakup tiga proses utama, yaitu formulate, employ dan interpret (Organisation for Economic Co-operation and Development, 2013). Proses "formulate" merujuk kepada kemampuan individu dalam mengenali dan mengidentifikasi peluang untuk menggunakan matematika dan menyajikan struktur matematika terhadap permasalahan kontekstual yang dihadapi. Proses "employ" merujuk kepada kemampuan individu dalam menerapkan konsep, fakta, prosedur dan penalaran matematika untuk menyelesaikan permasalahan yang telah diformulasikan untuk memperoleh solusi matematis. Proses "interpret" merujuk kepada kemampuan individu dalam merefleksi solusi, hasil, dan kesimpulan matematika serta menginterpretasikannya dalam permasalahan di kehidupan sehari-hari. Irisan antara domain proses PISA, matematisasi, dan pemodelan matematika ditunjukkan pada Tabel 1.

Tabel 1. Perbandingan Domain Proses Matematis PISA, Matematisasi dan Pemodelan Matematika

\begin{tabular}{lll}
\hline $\begin{array}{c}\text { Domain Proses } \\
\text { Matematis }\end{array}$ & \multicolumn{1}{c}{ Matematisasi } & \multicolumn{1}{c}{ Pemodelan Matematika } \\
\hline Formulate & $\begin{array}{l}\text { Mengidentifikasi ide matematika yang } \\
\text { relevan dan mengatur kembali }\end{array}$ & $\begin{array}{l}\text { Memahami ciri-ciri dari permasalahan dan } \\
\text { mengasumsikan berdasarkan konteks dan pengalaman. }\end{array}$
\end{tabular}
permasalahan tersebut berdasarkan ide matematika yang teridentifikasi Penyesuaian model matematika Simplifikasi, yakni menemukan struktur utama dari sehingga dapat diselesaikan. permasalahan.

Matematisasi, yakni mentranslasikan permasalahan dunia nyata ke dunia matematika. Tahapan ini dilakukan dengan mendeteksi ciri-ciri permasalahan dunia nyata yang berkorespondensi dengan konsep matematika.

\begin{tabular}{lll}
\hline Employ & $\begin{array}{l}\text { Menyelesaikan permasalahan yang } \\
\text { telah berupa model matematika }\end{array}$ & $\begin{array}{l}\text { Menyelesaikan permasalahan dengan konsep, } \\
\text { algoritma, atau rumus matematika tertentu. }\end{array}$ \\
\hline Interpret & Memberikan pemaknaan dari solusi & Menginterpretasikan dan mengevaluasi penyelesaian \\
& matematika dalam konteks kehidupan & matematika ke dalam dunia nyata. \\
nyata & $\begin{array}{l}\text { Melakukan validasi bahwa model matematika yang } \\
\text { digunakan konsisten dan sesuai dengan konteks dunia }\end{array}$ \\
& nyata. \\
& Mengkomunikasikan penyelesaian beserta \\
& argumentasinya. \\
\hline
\end{tabular}

(Blum, 2011; de Lange, 2006; Organisation for Economic Co-operation and Development, 2013)

Hasil penelitian PISA yang telah diikuti Indonesia sejak tahun 2000 menunjukkan bahwa ratarata skor literasi matematika siswa Indonesia pada usia kisaran 15 tahun masih di bawah standar internasional dan cenderung tidak mengalami peningkatan yang signifikan (Badan Penelitian dan Pengembangan, 2011; Organisation for Economic Co-operation and Development, 2016). Namun hasil ini belum mewakili kemampuan siswa Indonesia secara keseluruhan. Wulandari dan Jailani (2015, p. 195) menemukan bahwa sampel sekolah yang digunakan pada penelitian PISA di Indonesia menggunakan sekolah-sekolah dengan kategori rendah. Pusztai \& Bacskai (2015, p. 148) juga berpendapat bahwa database PISA memiliki gambaran yang tidak terstruktur sehingga belum mewakili semua tipe sekolah. Hal ini berdampak terhadap seleksi sekolah yang bias sehingga berpengaruh terhadap penskoran dan ranking (Tienken, 2014, p. 9). Oleh karena itu, perlu upaya penelitian secara mendalam di setiap wilayah sebagai pelengkap informasi dan pembanding terhadap hasil PISA, sehingga hasilnya menjadi lebih representatif dan matang untuk dijadikan pertimbangan dalam mengambil kebijakan pendidikan.

Kalimantan Timur sebagai provinsi yang berada di Indonesia bagian tengah merupakan wilayah yang belum pernah menjadi sampel untuk penelitian tentang kemampuan PISA. Padahal kondisi geografi dan posisinya yang jauh dari pusat pemerintahan sangat memungkinkan terjadi perbedaan karakteristik kemampuan siswanya. Oleh karena itu, penelitian ini dilakukan untuk mendeskripsikan kemampuan literasi matematika siswa Kalimantan Timur, khususnya pada kemampuan proses matematis pada PISA. 


\section{METODE}

Penelitian ini merupakan penelitian kuantitatif berupa survei yang bertujuan untuk mengumpulkan informasi tentang karakteristik suatu populasi berdasarkan temuan-temuan yang diperoleh dari sampel (Ary et al., 2018, p. 372; Novferma, 2016). Penelitian ini bersifat deskriptif (Cohen et al., 2007, p. 205), yakni penelitian ini mendeksripsikan kemampuan proses matematis siswa Kalimantan Timur. Penelitian dilaksanakan di Provinsi Kalimantan Timur selama bulan Maret hingga April 2017. Kalimantan Timur merupakan provinsi di wilayah Indonesia bagian tengah yang memiliki 10 kabupaten/kota dan 589 SMP, baik yang berstatus negeri maupun swasta (Pusat Penelitian Pendidikan Kementerian Pendidikan dan Kebudayaan Republik Indonesia, 2018).

\section{Populasi dan Sampel Penelitian}

Populasi penelitian adalah seluruh siswa SMP kelas IX di Kalimantan Timur yang pada tahun 2017 sebanyak 48.460 siswa (Pusat Penelitian Pendidikan Kementerian Pendidikan dan Kebudayaan Republik Indonesia, 2018). Berdasarkan hasil UN pada tahun 2015 dan 2016, kemampuan matematika siswa SMP Kalimantan Timur mengalami peningkatan meskipun masih tergolong rendah, yakni dari 47,71 menjadi 52,31 (Pusat Penelitian Pendidikan Kementerian Pendidikan dan Kebudayaan Republik Indonesia, 2018). Kondisi ini berbeda dengan nilai UN Matematika siswa SMP secara nasional yang justru mengalami penurunan. Siswa kelas IX dipilih karena rata-rata usia mereka sesuai dengan kriteria populasi PISA, yaitu anak usia 15 tahun. Hal ini berdasarkan syarat usia anak masuk sekolah yang serendah-rendahnya adalah enam tahun sehingga usia siswa kelas IX adalah sekitar 15 tahun.

Ukuran populasi yang sangat besar memerlukan sampel penelitian. Sampel penelitian ini diambil dengan menggunakan prinsip dasar dari penelitian kuantitatif, yaitu 100 sampel pada masing-masing sub grup (Gall et al., 2003, p. 290). Penelitian ini menggunakan kriteria sub grup berupa kategori sekolah berdasarkan hasil Ujian Nasional (UN) tahun 2016 pada mata pelajaran matematika, yakni kategori A (tinggi), B (sedang) dan C (rendah). Dengan demikian, banyak sampel penelitian adalah 300 siswa kelas IX SMP di Kalimantan Timur. Rincian sampel penelitian dijelaskan pada Tabel 2.

Teknik penentuan sampel yang digunakan merupakan kombinasi teknik nonproportional stratified sampling, convenience sampling, dan cluster sampling (Gall et al., 2003, pp. 173-176). Daftar sekolah dan banyak siswa yang menjadi sampel penelitian ini dijelaskan pada Tabel 2. Sampel pada penelitian ini tidak sama dengan sampel yang digunakan oleh PISA dalam mengukur kemampuan matematika siswa Indonesia. Perbedaan sumber data berimplikasi kepada perbandingan antara kemampuan siswa pada penelitian ini dan siswa Indonesia yang diteliti oleh PISA menjadi kurang sepadan. Sehingga perbandingan yang peneliti lakukan bertujuan menambah keluasan informasi tentang kemampuan literasi matematika di Indonesia, khususnya Kalimantan Timur.

\section{Teknik dan Instrumen Pengumpulan Data}

Pengumpulan data pada penelitian ini menggunakan instrumen tes tertulis berupa soal matematika model PISA. Soal model PISA dibuat sebanyak satu paket yang terdiri dari 16 butir soal yang terdiri dari bentuk pilihan ganda, isian singkat dan uraian (Tabel 3). Paket soal model PISA tersebut akan dikerjakan oleh siswa selama 30 menit, sesuai dengan alokasi waktu dalam tes PISA yang sebenarnya (Organisation for Economic Co-operation and Development, 2014a, p. 36). Paket soal model PISA untuk mengukur kemampuan proses matematis berdasarkan framework literasi matematika, khususnya domain proses. Rincian tentang persentase butir soal berdasarkan domain proses matematis dan konten matematika dijelaskan pada Tabel 4 dan Tabel 5. Instrumen telah divalidasi oleh pakar di bidang pengembangan instrumen soal PISA. Berdasarkan hasil uji coba diperoleh estimasi reliabilitas sebesar 0,835 yang berarti memenuhi standar minimum reliabilitas instrumen yang digunakan untuk mengukur skor sekelompok individu (Ebel \& Frisbie, 1991).

\section{Teknik Analisis Data}

Data berupa jawaban siswa diberi skor berdasarkan kunci jawaban dan rubrik penskoran yang telah disusun sehingga diperoleh skor siswa per butir soal maupun secara keseluruhan. Selanjutnya, skor siswa tersebut dideskripsikan menggunakan statistik deskriptif yang meliputi, rata-rata, simpangan baku, skor tertinggi, dan skor terendah.

Selanjutnya, digunakan teori respon butir dengan model satu parameter untuk memperoleh ratarata kemampuan siswa dalam bentuk skala logit dengan bantuan aplikasi Winstep. Kemampuan siswa 
dalam skala logit tersebut dikonversi ke dalam skala PISA dengan Persamaan Rumus 1. Dari Persamaan Rumus 1 diketahui bahwa P adalah skor dalam skala PISA, dan L adalah kemampuan siswa dalam skala logit.

$\mathrm{P}=((L+0.0981) / 1.2838) \times 100+500$

(Organisation for Economic Co-operation and Development, 2014a, p. 253).

Skor siswa dalam skala PISA tersebut digunakan untuk mendeskripsikan kemampuan literasi matematika siswa Kalimantan Timur secara umum yang ditunjukkan dengan level kecakapan matematika siswa dengan interval skala PISA, sebagaimana disajikan pada Tabel 6. Selain itu, skor tersebut juga digunakan untuk mendeskripsikan kemampuan proses matematis siswa secara khusus, yakni proses formulate, employ, dan interpret.

Tabel 2. Daftar Sekolah dan Banyak Siswa $(N)$ untuk Sampel Penelitian

\begin{tabular}{|c|c|c|c|}
\hline Nama Sekolah & Kabupaten/Kota & Kategori & $N$ \\
\hline SMP IT DHBS & Bontang & $\mathrm{A}$ & 25 \\
\hline SMP Budi Bakti & Samarinda & A & 21 \\
\hline SMP YPK & Kutai Kartanegara & A & 24 \\
\hline \multirow[t]{2}{*}{ SMPN 1} & Balikpapan & A & 30 \\
\hline & & Sub Total & 100 \\
\hline SMP Ibnu Sina & Kutai Timur & $\mathrm{B}$ & 17 \\
\hline SMP Muhammadiyah 3 & Samarinda & $\mathrm{B}$ & 24 \\
\hline SMPN 2 Damai & Kutai Barat & $\mathrm{B}$ & 35 \\
\hline \multirow[t]{2}{*}{ SMPN 10} & Penajam Paser Utara & B & 24 \\
\hline & & Sub Total & 100 \\
\hline SMPN 2 & Berau & $\mathrm{C}$ & 20 \\
\hline SMPN 2 Tenggarong & Kutai Kartanegara & $\mathrm{C}$ & 27 \\
\hline SMP Muhammadiyah 1 & Samarinda & $\mathrm{C}$ & 30 \\
\hline \multirow[t]{3}{*}{ SMP Nusantara } & Balikpapan & $\mathrm{C}$ & 23 \\
\hline & & Sub Total & 100 \\
\hline & & Total Sampel & 300 \\
\hline
\end{tabular}

Tabel 3. Rincian Bentuk Soal Matematika Model PISA

\begin{tabular}{lc}
\hline \multicolumn{1}{c}{ Bentuk Soal } & Banyak Butir Soal \\
\hline Multiple choice (pilihan ganda) & 8 \\
Closed constructed response (jawaban tertutup) & 5 \\
Open constructed response (jawaban terbuka) & 3 \\
\hline
\end{tabular}

Tabel 4. Persentase Butir Soal Berdasarkan Domain Proses Matematis

\begin{tabular}{lcc}
\hline Domain Proses & Banyak Butir Soal & Persentase $(\%)$ \\
\hline Formulate & 4 & 25 \\
Employ & 8 & 50 \\
Interpret & 4 & 25 \\
\hline
\end{tabular}

Tabel 5. Persentase Butir Soal Berdasarkan Konten Matematika

\begin{tabular}{lcc}
\hline \multicolumn{1}{c}{ Domain Konten } & Banyak Butir Soal & Persentase $(\%)$ \\
\hline Quantity & 4 & 25 \\
Change and relationship & 4 & 25 \\
Space and shape & 4 & 25 \\
Uncertainty and data & 4 & 25 \\
\hline
\end{tabular}

Tabel 6. Level Kecakapan Matematika Siswa Berdasarkan Skor PISA

\begin{tabular}{lc}
\hline Interval Skor Matematika PISA & Level \\
\hline $669 \leq X$ & 6 \\
$607 \leq X<669$ & 5 \\
$545 \leq X<607$ & 4 \\
$482 \leq X<545$ & 3 \\
$420 \leq X<482$ & 2 \\
$358 \leq X<420$ & 1 \\
$X<358$ & Di bawah 1 \\
\hline
\end{tabular}




\section{HASIL DAN PEMBAHASAN}

\section{Kemampuan Siswa Kalimantan Timur Secara Keseluruhan}

Deskripsi kemampuan siswa Kalimantan Timur dalam menyelesaikan soal matematika model PISA secara umum dan berdasarkan kategori sekolah dijelaskan pada Tabel 7 dan Tabel 8. Melalui teori respon butir dengan bantuan Winstep, diperoleh Mean Logit Measure sebesar -1,18. Lebih detail, Mean Logit Measure siswa dari sekolah kategori A, B, dan C masing-masing sebesar -0,35; -1,67; dan -1,51. Jika dikonversi ke dalam skala matematika PISA, maka diperoleh rata-rata skor matematika PISA siswa kategori A, B, dan C, serta Kalimantan Timur secara umum masing-masing sebesar 480,42; 377,36; 389,45; dan 415,72. Perbandingan rata-rata skor matematika PISA siswa dari sekolah kategori A, B, C, Kalimantan Timur secara umum, Indonesia, dan OECD ditunjukkan pada Gambar 1.

Tabel 7. Deskripsi Kemampuan Siswa dalam Menyelesaikan Soal Matematika Model PISA

\begin{tabular}{lccc}
\hline Statistik Deskriptif & Skor Murni & Skala Logit & Skala PISA \\
\hline Rata-rata & 5,93 & $-1,18$ & 415,72 \\
Simpangan baku & 3,47 & 1,09 & 592,54 \\
Nilai tertinggi & 18 & 2,58 & 708,61 \\
Nilai terendah & 1 & $-3,52$ & 233,46 \\
\hline
\end{tabular}

Tabel 8. Rata-Rata Skor Kemampuan dalam Menyelesaikan Soal Matematika Model PISA Berdasarkan Kategori Sekolah

\begin{tabular}{lrrr}
\hline Kategori Sekolah & Skor Murni & \multicolumn{1}{c}{ Skala Logit } & \multicolumn{1}{c}{ Skala PISA } \\
\hline A & 8,72 & $-0,35$ & 480,42 \\
B & 4,27 & $-1,67$ & 377,36 \\
C & 4,81 & $-1,51$ & 389,45 \\
\hline
\end{tabular}

Gambar 1 menunjukkan bahwa rata-rata skor matematika PISA siswa Kalimantan Timur lebih tinggi daripada siswa Indonesia yang menjadi sampel pada PISA 2000-2015. Meskipun begitu, rata-rata skor tersebut masih berada di bawah rata-rata OECD. Lebih detail, rata-rata skor PISA dari sekolah kategori A lebih tinggi dari rata-rata skor PISA siswa Kalimantan Timur secara keseluruhan.

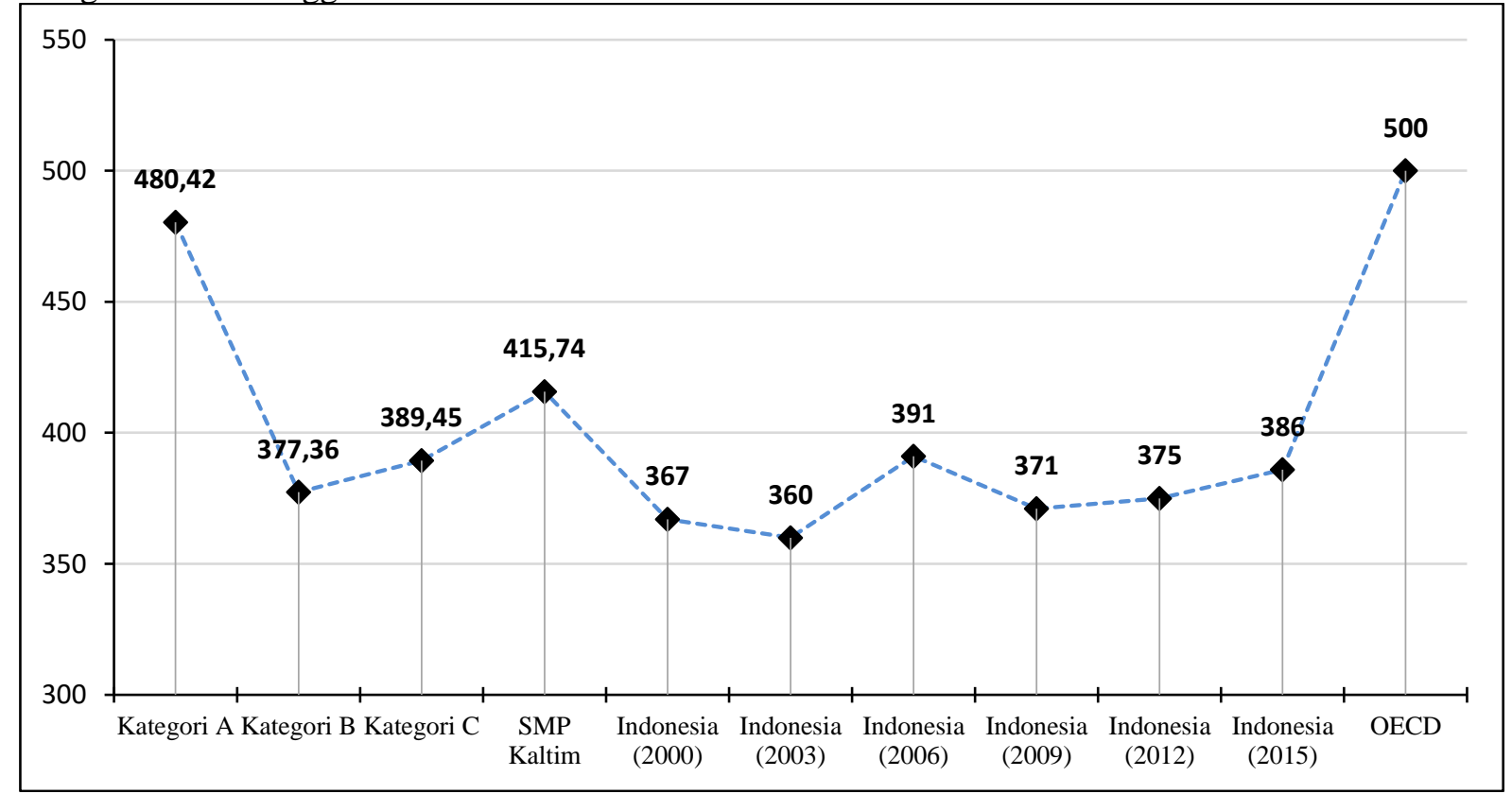

Gambar 1. Perbandingan Rata-Rata Skor Matematika PISA (Badan Penelitian dan Pengembangan, 2011; Organisation for Economic Co-operation and Development, 2016, p. 177)

Meskipun rata-rata siswa Kalimantan Timur secara keseluruhan (415,740 masih di bawah ratarata skor negara-negara OECD (500), namun rata-rata skor PISA dari sekolah kategori C $(389,45)$ lebih tinggi dari pada rata-rata skor PIS A siswa Indonesia yang menjadi sampel pada PISA 2015 (386). Hasil penelitian ini menunjukkan bahwa literasi matematika siswa Kalimantan Timur tergolong rendah, yakni 


\section{Jurnal Riset Pendidikan Matematika, 6 (2), 2019 - 139}

Anwaril Hamidy, Jailani Jailani

rata-rata skor PISA siswa Kalimantan Timur yang masih di bawah rata-rata OECD. Literasi matematika tersebut berkaitan dengan kompetensi siswa dalam menganalisa, menalar, dan mengkomunikasikan secara efektif rumusan, penyelesaian, dan penafsiran masalah dalam berbagai situasi (Sáenz, 2009, p. 124). Dengan demikian, secara umum kompetensi siswa Kalimantan Timur dalam menganalisa, menalar, mengkomunikasikan, sebagaimana telah disebutkan sebelumnya masih perlu ditingkatkan.

Rendahnya literasi matematika siswa Indonesia secara umum, maupun siswa Kalimantan Timur secara khusus dipengaruhi oleh kesulitan guru dalam menghadirkan pembelajaran yang melatihkan Higher Order Thinking Skills (HOTS) di kelas. Hal ini didukung oleh hasil penelitian Demir (2018) yang menemukan bahwa terdapat hubungan positif antara kemampuan guru mengaktifkan kemampuan kognitif siswa dan kemampuan matematika siswa. Artinya, kemampuan guru dalam mengajarkan HOTS berdampak kepada literasi matematika siswa. Hasil penelitian Afifah dan Retnawati (2019) juga menemukan fakta bahwa kesulitan guru dalam mengajarkan HOTS berasal dari rendahnya pengetahuan tentang HOTS sehingga berdampak kepada kesulitan dalam merancang pembelajaran dan penilaian berdasarkan HOTS.

Namun, jika dibandingkan dengan hasil siswa Indonesia yang menjadi sampel PISA 2000-2015, literasi matematika siswa Kalimantan Timur lebih baik (lihat Gambar 1). Hasil ini memiliki kesamaan dengan penelitian Wijaya et al. (2014, p. 564) dan Wulandari (2015, p. 138), yakni kemampuan siswa usia 15 tahun di SMP dan SMA Daerah Istimewa Yogyakarta dalam menyelesaikan soal model PISA lebih tinggi dari capaian siswa Indonesia yang menjadi sampel PISA. Lebih detail, skor matematika siswa Kalimantan Timur dari sekolah kategori B (sedang) dan C (rendah) relatif sama dengan capaian siswa Indonesia yang menjadi sampel PISA tahun 2000 hingga 2015. Sedangkan capaian siswa dari sekolah kategori A (tinggi) jauh lebih tinggi dari pada capaian siswa Kalimantan Timur secara keseluruhan dan capaian siswa Indonesia yang menjadi sampel PISA. Hal ini menunjukkan bahwa skor siswa Kalimantan Timur yang lebih tinggi dari pada siswa Indonesia yang menjadi sampel PISA merupakan kontribusi dari siswa yang berasal dari sekolah dengan kategori A (tinggi), yakni sekolah dengan nilai UN tahun 2016 pada mata pelajaran matematika yang tergolong tinggi. Artinya, ada hubungan yang positif antara hasil Ujian Nasional dengan capaian skor PISA, sebagaimana juga hasil penelitian Indartono dan Hamidy (2019) dan Kaleli-Y1lmaz dan Hanci (2016).

\section{Kemampuan Siswa Kalimantan Timur Berdasarkan Level Kecakapan Matematika}

Organisation for Economic Co-operation and Development (2014b, p. 68) menetapkan level 2 sebagai level kecakapan matematika terendah dari literasi matematika, yakni siswa mampu menginterpretasikan dan mengenali situasi konteks dengan cara menyimpulkan secara langsung; mengekstraksi informasi yang relevan dari satu sumber dan hanya menggunakan representasi tunggal; melakukan algoritma, prosedur, dan rumus dasar; serta membuat interpretasi literal dari hasil penyelesaian. Berdasarkan interval skor pada level kecakapan matematika PISA, kecakapan matematika siswa SMP Kalimantan Timur berada pada level 1. Lebih detail, rata-rata kemampuan siswa dari sekolah A, B, dan $\mathrm{C}$ berturut-turut berada pada level 2, level 1, dan level 1. Persentase siswa dari sekolah kategori A, B, dan C pada setiap level kecakapan matematika PISA serta perbandingannya dengan capaian siswa SMP Kalimantan Timur secara umum, sampel Indonesia pada studi PISA, dan OECD ditunjukkan pada Tabel 9 dan Gambar 2. Tabel 9 dan Gambar 2 menunjukkan bahwa persentase terbesar siswa dari negara OECD pada PISA 2015 berada pada level 3, dimana persentase siswa Kalimantan Timur dan Indonesia pada level yang sama berturut-turut adalah sebesar $10 \%$ dan $8,4 \%$. Sedangkan persentase terbesar siswa Kalimantan Timur dan Indonesia berada di bawah level 1, dimana persentase siswa dari negara OECD pada level yang sama hanya sebesar $8,5 \%$. Meskipun sebagian besar siswa Kalimantan Timur maupun siswa Indonesia masih berada di bawah level 2, persentase siswa Kalimantan Timur yang berada di level 2 ke atas lebih tinggi daripada persentase siswa Indonesia yang menjadi sampel pada PISA 2012. Artinya, persentase siswa Kalimantan Timur yang memiliki standar minimal kecakapan matematika versi PISA lebih tinggi dari pada persentase siswa Indonesia yang menjadi sampel pada PISA 2012. Hasil yang mirip juga ditemukan oleh Wulandari (2015), yakni persentase siswa Daerah Istimewa Yogyakarta (DIY) yang memiliki kemampuan matematika pada level 2 ke atas lebih tinggi dari pada siswa Indonesia pada PISA. Selain itu, terdapat 0,7\% dari siswa Kalimantan Timur yang memiliki kecakapan matematika level 6, sedangkan pada PISA 2015 terdapat 0,1\% dari siswa Indonesia yang memiliki kecakapan matematika level 6. 
Jurnal Riset Pendidikan Matematika, 6 (2), 2019 - 140

Anwaril Hamidy, Jailani Jailani

Tabel 9. Persentase Siswa pada Setiap Level Kemampuan Matematika PISA

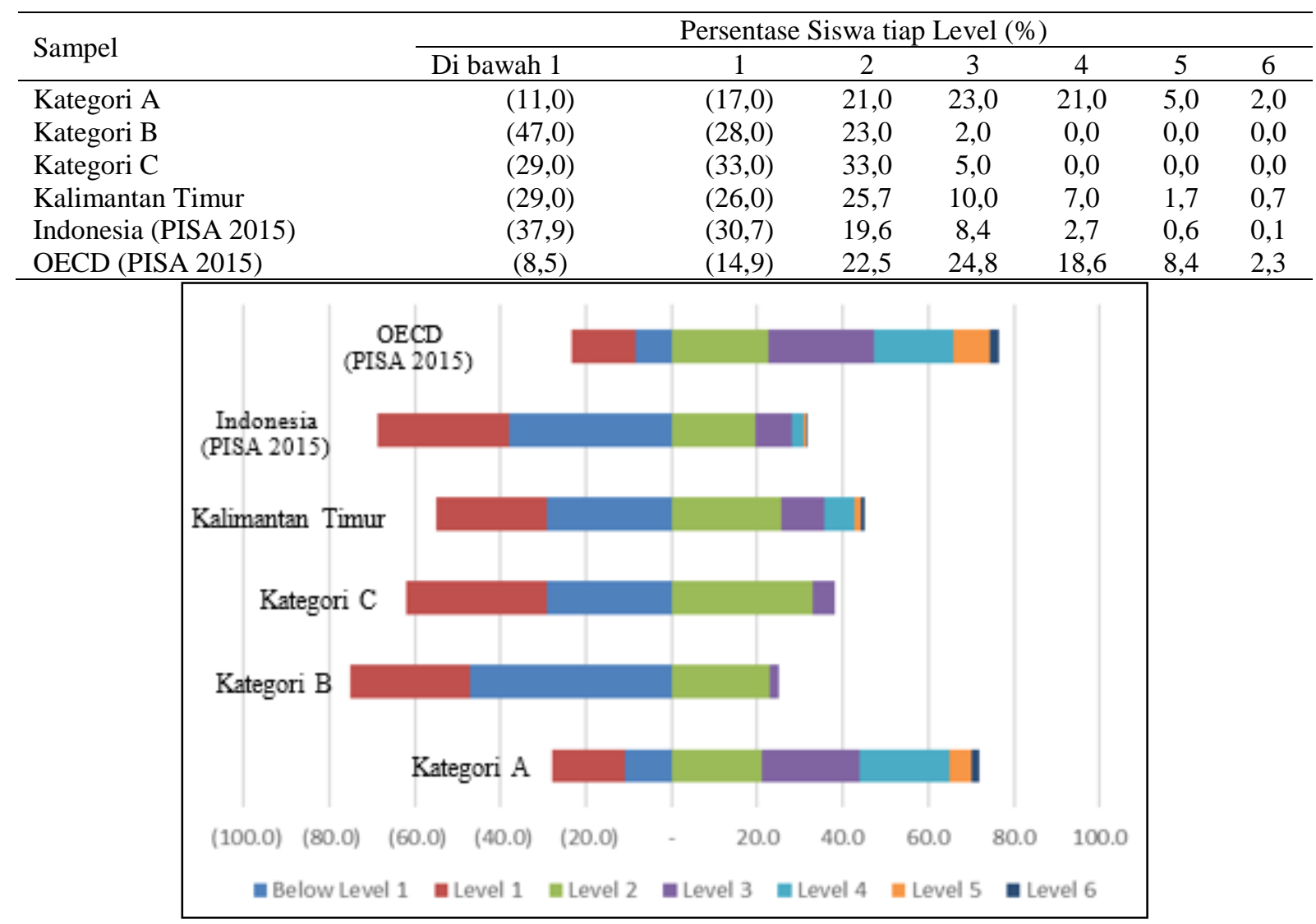

Gambar 2. Persentase Siswa pada Setiap Level Kecakapan Matematika PISA (Organisation for Economic Co-operation and Development, 2016, p. 177)

Lebih detail, terdapat $28 \%$ siswa Kalimantan Timur yang memiliki kecakapan matematika pada level 4-6. Pada level ini siswa mampu berpikir tingkat tinggi seperti menganalisis, mengevaluasi dan mencipta (Setiawan, Dafik, \& Lestari, 2014). Jika dilihat berdasarkan kategori sekolah, maka 28\% siswa dengan kemampuan berpikir tingkat tinggi tersebut berasal dari sekolah kategori A. Selain itu, persentase siswa dari sekolah kategori A pada level 6 hampir sama dengan persentase siswa dari negara OECD pada PISA 2015. Sedangkan sekolah kategori B dan C tidak terdapat seorang siswa yang berada pada level 4-6. Artinya, siswa dengan kemampuan berpikir tingkat tinggi tidak ditemukan pada sekolah dengan nilai UN matematika yang tergolong sedang dan rendah. Hal ini menunjukkan bahwa siswa dari sekolah dengan hasil UN matematika kategori tinggi dalam memberikan kontribusi positif terhadap persentase siswa Kalimantan Timur yang memiliki kemampuan matematika level tinggi. Dengan demikian, perbedaan literasi matematika antara siswa Kalimantan Timur dan Indonesia disebabkan oleh faktor keterwakilan tipe sekolah, yakni sampel sekolah yang digunakan pada penelitian PISA di Indonesia menggunakan sekolah-sekolah dengan kategori rendah (Wulandari \& Jailani, 2015).

Meskipun lebih baik dibandingkan capaian siswa Indonesia yang menjadi sampel PISA, skor PISA dan persentase siswa Kalimantan Timur pada level 2 ke atas maupun pada level 6 masih di bawah siswa dari negara OECD pada PISA 2015. Artinya, sebagian besar siswa Kalimantan Timur belum mampu dalam menerapkan pengetahuan dan keterampilan matematika yang diperoleh di sekolah dalam menyelesaikan permasalahan kontekstual. Rendahnya kemampuan siswa Kalimantan Timur dalam menyelesaikan soal matematika model PISA menunjukkan bahwa kompetensi matematika siswa SMP yang dirumuskan pada KTSP dan Kurikulum 2013 belum sepenuhnya tercapai, meskipun telah mengakomodasi aspek-aspek dari literasi matematika. Hal ini didukung oleh pernyataan Wardhani dan Rumiati (2011); Ahyan, Zulkardi dan Darmawijoyo (2014) bahwa dalam praktik pembelajaran, penggunaan permasalahan yang memiliki karakter seperti soal PISA dalam proses pembelajaran matematika di Indonesia masih dinilai kurang. Hasil penelitian Umbara dan Suryadi (2019) juga menunjukkan bahwa $60 \%$ dari 20 guru matematika memiliki pengetahuan yang minim tentang literasi matematika. 
Hal ini berdampak kepada minimnya pembelajaran dan penilaian yang mengacu kepada literasi matematika, yakni masing-masing 3,63\% dan 2,47\% .

\section{Kemampuan Siswa Kalimantan Timur Berdasarkan Domain Proses Matematis}

Deskripsi kemampuan siswa Kalimantan Timur dalam menyelesaikan soal matematika model PISA berdasarkan domain proses matematis dijelaskan pada Tabel 10.

Tabel 10. Rata-Rata Kemampuan Siswa Berdasarkan Domain Proses Matematis

\begin{tabular}{lrrr}
\hline Domain Proses & Skor Murni & \multicolumn{1}{c}{ Skala Logit } & Skala PISA \\
\hline Formulate & 2,25 & $-0,47$ & 471,03 \\
Employ & 2,51 & $-1,43$ & 396,25 \\
Interpret & 1,17 & $-1,79$ & 368,21 \\
\hline
\end{tabular}

Tabel 10 menunjukkan bahwa kemampuan siswa dalam mengidentifikasi dan memformulasikan permasalahan kontekstual ke dalam struktur matematika (formulate) lebih baik dari pada kemampuan proses matematis lainnya. Selain itu, kemampuan siswa dalam menginterpretasikan solusi matematika dalam kehidupan sehari-hari merupakan yang paling rendah dibandingkan kemampuan lainnya.

Perbandingan rata-rata skor PISA siswa Kalimantan Timur, Indonesia, dan OECD berdasarkan domain proses matematis ditunjukkan pada Gambar 3.

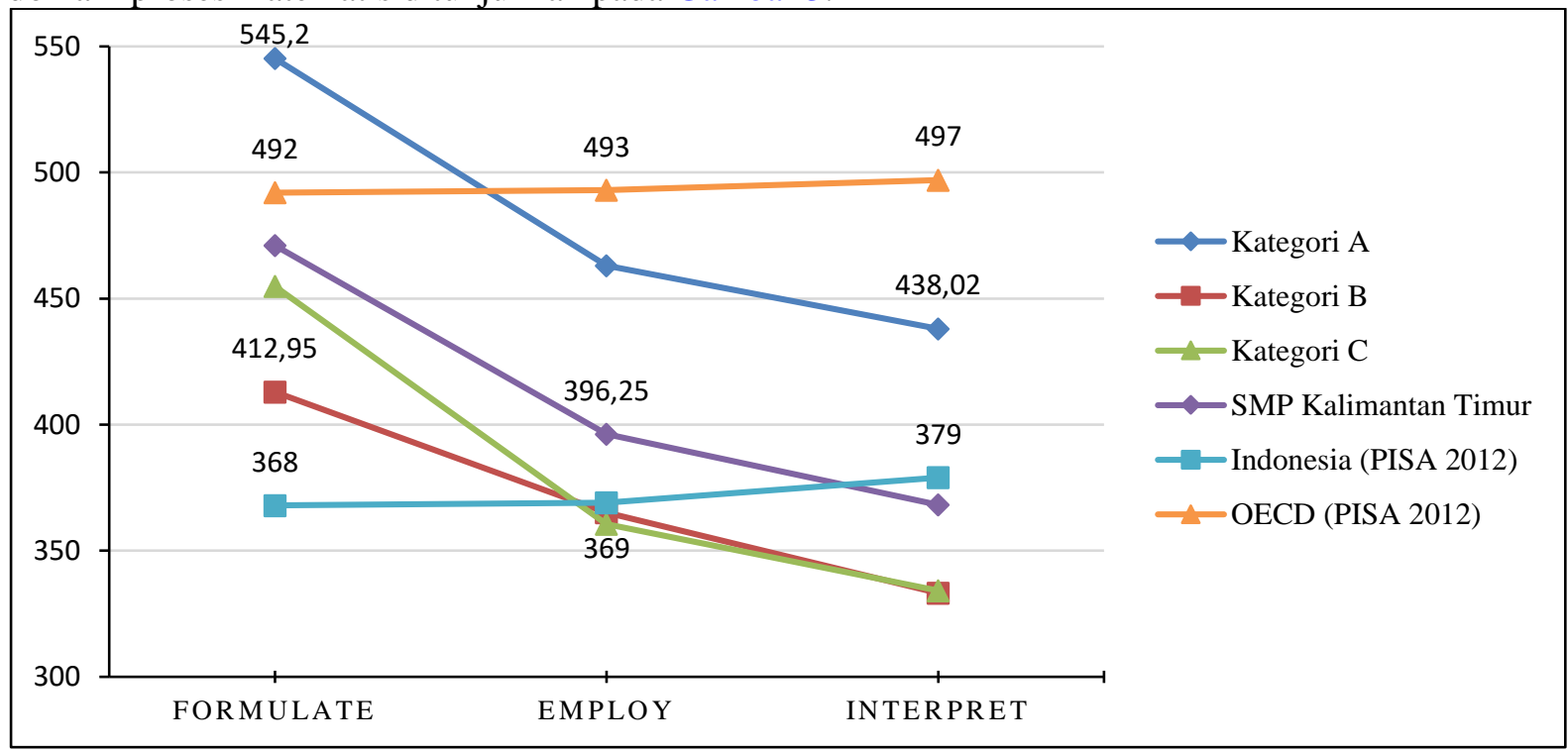

Gambar 3. Rata-Rata Skor Matematika PISA Berdasarkan Domain Proses Matematis (Organisation for Economic Co-operation and Development, 2013)

Gambar 3 menunjukkan bahwa skor matematika siswa Kalimantan Timur pada proses formulate dan employ lebih tinggi dari pada siswa Indonesia yang menjadi sampel PISA 2012. Sedangkan skor pada proses interpret siswa Kalimantan Timur lebih rendah daripada siswa Indonesia yang menjadi sampel PISA 2012. Selain itu, proses formulate merupakan domain proses yang paling tinggi dibandingkan domain proses lainnya pada siswa Kalimantan Timur. Berbeda dengan capaian siswa Kalimantan Timur, skor matematika siswa Indonesia yang menjadi sampel PISA dan skor negara-negara OECD (PISA 2012) pada proses interpret merupakan yang paling tinggi dibandingkan kemampuan pada proses lainnya. Secara umum, skor matematika siswa Kalimantan Timur dalam menyelesaikan soal matematika model PISA berdasarkan domain proses matematis masih berada di bawah rata-rata OECD.

Lebih detail, skor matematika siswa dari sekolah kategori A pada semua aspek domain proses matematis lebih tinggi dari pada siswa Kalimantan Timur dan siswa Indonesia yang menjadi sampel PISA. Bahkan pada proses formulate, capaian siswa dari sekolah kategori A lebih tinggi dari pada ratarata negara OECD. Selain itu, meskipun skor matematika siswa dari sekolah kategori B dan C pada semua aspek domain proses di bawah skor rata-rata siswa Kalimantan Timur dan rata-rata skor siswa Indonesia yang menjadi sampel PISA, namun skor matematika siswa pada proses formulate dari sekolah kategori C lebih tinggi dari pada skor siswa dari sekolah kategori B. Sedangkan pada domain employ dan interpret, skor matematika kedua kategori sekolah tersebut relatif sama. Dengan demikian, yang 
menyebabkan skor matematika siswa dari sekolah kategori $\mathrm{C}$ lebih tinggi dari pada siswa dari sekolah kategori B adalah skor matematika siswa pada proses formulate.

Hasil penelitian tersebut menunjukkan bahwa kemampuan siswa Kalimantan Timur pada proses formulate lebih baik dari pada siswa Indonesia yang menjadi sampel PISA. Bahkan kemampuan siswa Kalimantan Timur dari sekolah kategori A pada proses formulate lebih baik dari pada siswa dari negara OECD. Hal ini menunjukkan bahwa siswa Kalimantan Timur mampu mengenali dan mengidentifikasi peluang untuk menggunakan matematika serta menyajikan struktur matematika terhadap permasalahan kontekstual yang dihadapi lebih baik, dibandingkan siswa Indonesia yang menjadi sampel PISA. Jika dikaitkan dengan proses matematisasi dan pemodelan matematika (Blum, 2011; de Lange, 2006), maka siswa Kalimantan Timur mampu mengidentifikasi ide matematika pada suatu konteks masalah, mentranslasikan masalah ke bentuk matematika dan menyesuaikannya dengan model matematika dengan baik. Adapun soal matematika model PISA yang memuat proses formulate disajikan pada Gambar 4.

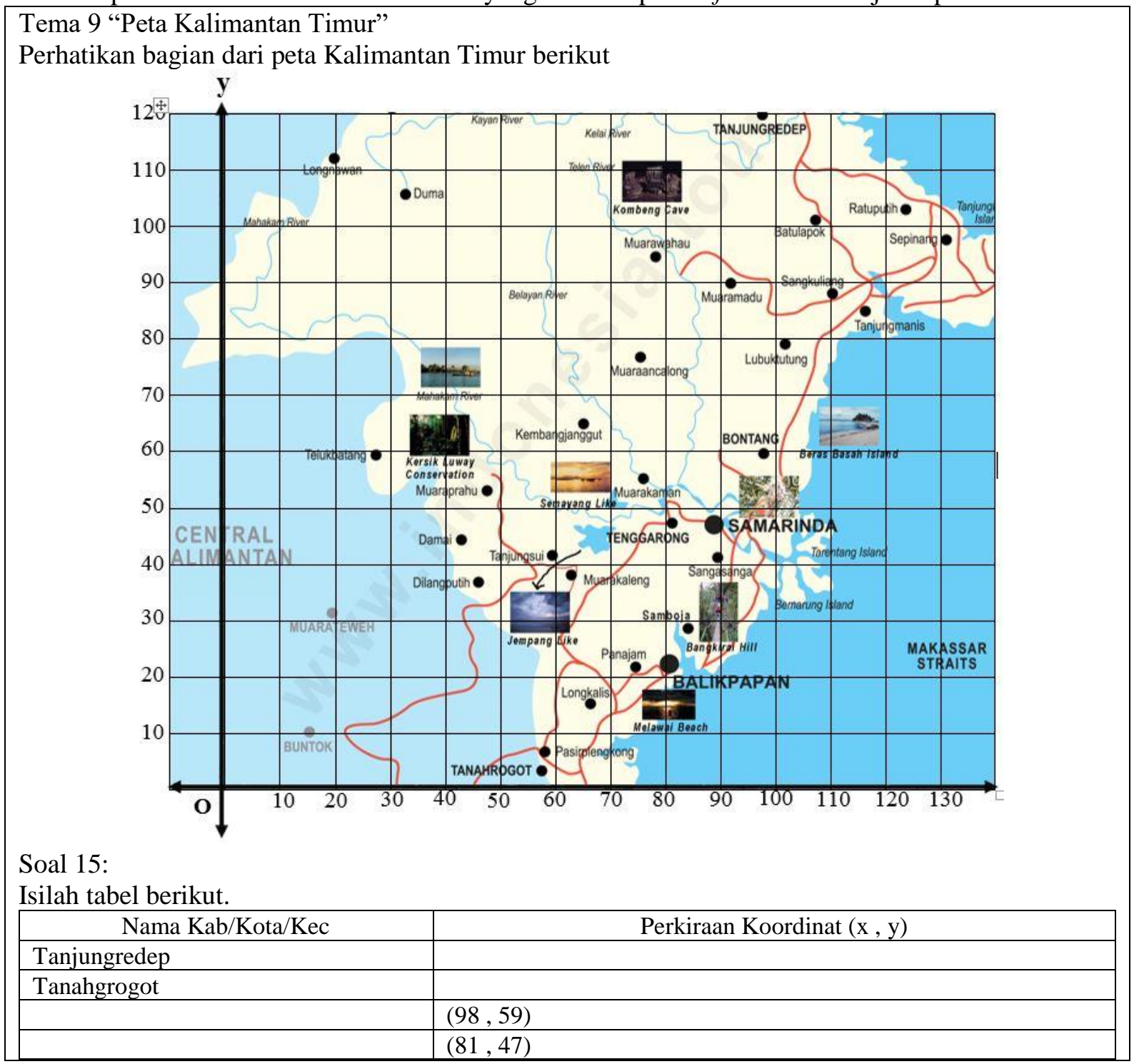

Gambar 4. Contoh Soal Model PISA Domain Proses Formulate

Soal pada Gambar 4 mengukur kemampuan siswa dalam membaca suatu representasi berupa sistem koordinat untuk menentukan lokasi suatu daerah. Menentukan lokasi suatu titik pada sistem koordinat memerlukan pemahaman konsep tentang sistem koordinat, cara membacanya serta kemampuan mengestimasi berdasarkan skala yang telah ditetapkan. Dengan demikian, kompetensi matematika yang digunakan adalah komunikasi dan representasi (Organisation for Economic Co-operation and Development, 2013). Contoh jawaban siswa yang tergolong benar (Gambar 5), sebagian benar (Gambar 6), dan salah (Gambar 7) adalah sebagai berikut. 
Jurnal Riset Pendidikan Matematika, 6 (2), 2019 - 143

Anwaril Hamidy, Jailani Jailani

\begin{tabular}{|l|l|}
\hline \multicolumn{1}{|c|}{ Nama Kab/Kota/Kec } & Perkiraan Koordinat $(x, y)$ \\
\hline Tanjungredep & $(98,120)$ \\
\hline Tanahgrogot & $(58,4)$ \\
\hline Bontang & $(98,59)$ \\
\hline Tenggarong & $(81,47)$ \\
\hline
\end{tabular}

Gambar 5. Contoh Jawaban Benar Soal Model PISA Domain Proses Formulate

Contoh jawaban siswa pada Gambar 5 menunjukkan bahwa siswa mampu membaca peta dalam sistem koordinat, mengestimasi lokasi suatu titik dan menyajikannya dalam bentuk titik koordinat dengan tepat.

\begin{tabular}{|l|l|}
\hline Nama Kab/Kota/Kec & Perkiraan Koordinat $(x, y)$ \\
\hline Tanjungredep & $95,6 \cdot$ \\
\hline Tanahgrogot & 57,3 \\
\hline Bonfare9 & $(98,59)$ \\
\hline Tengearone & $(81,47)$ \\
\hline
\end{tabular}

Gambar 6. Contoh Jawaban Sebagian Benar Soal Model PISA Domain Proses Formulate

Contoh jawaban siswa pada Gambar 6 menunjukkan bahwa siswa lemah dalam kemampuan representasi matematika. Meskipun mereka mampu membaca peta dalam sistem koordinat, terdapat siswa yang tidak memahami penyajian lokasi suatu titik pada sistem koordinat ataupun keliru dalam mengestimasi lokasi suatu titik.

\begin{tabular}{|l|l|}
\hline \multicolumn{1}{|c|}{ Nama Kab/Kota/Kec } & Perkiraan Koordinat $(x, y)$ \\
\hline Tanjungredep & $(20, \pm 0)$ \\
\hline Tanahgrogot & $(3,58)$ \\
\hline Balik Yapan & $(98,59)$ \\
\hline Samar i Ad9 & $(81,47)$ \\
\hline
\end{tabular}

Gambar 7. Contoh Jawaban Salah Soal Model PISA Domain Proses Formulate

Contoh jawaban siswa pada Gambar 7 menunjukkan bahwa siswa lemah dalam kemampuan komunikasi dan representasi matematika, yakni tidak mampu membaca peta dalam sistem koordinat, mengestimasinya, maupun menyajikannya dengan tepat. Selain itu, terdapat beberapa siswa yang tidak menjawab soal ini karena menganggap sulit dalam membaca dan mencari titik lokasi atau kehabisan waktu dalam mengerjakan. Persentase jawaban seluruh siswa untuk soal pada Gambar 4 disajikan pada Gambar 8.

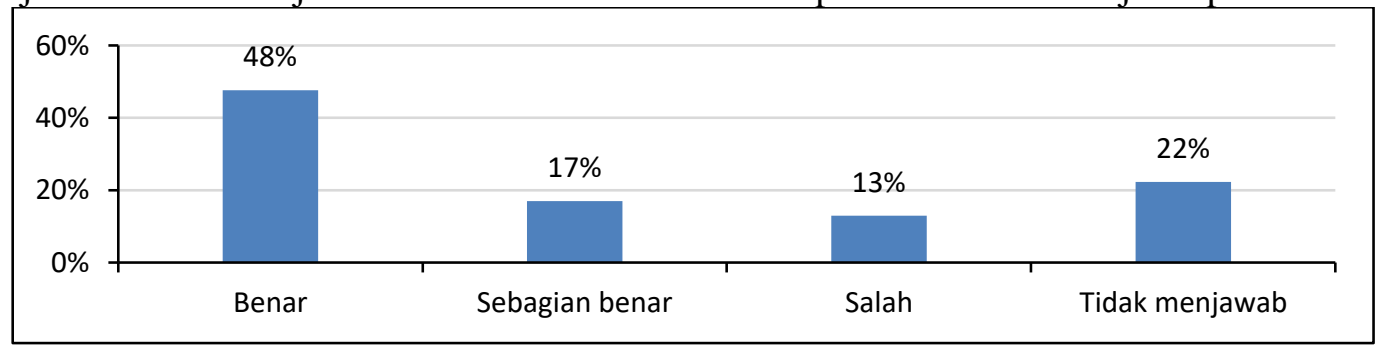

Gambar 8. Persentase Jawaban Siswa pada Contoh Soal Model PISA Domain Proses Formulate

Tingginya persentase siswa yang menjawab benar menunjukkan siswa mampu membaca peta dalam sistem koordinat, mengestimasi lokasi suatu titik dan menyajikannya dalam bentuk titik koordinat dengan tepat. 
Kemampuan siswa Kalimantan Timur pada proses employ lebih rendah dari pada proses formulate, meskipun masih lebih baik dari pada capaian siswa Indonesia yang menjadi sampel pada PISA 2012. Kemampuan proses employ merupakan kemampuan siswa dalam menerapkan konsep, fakta, prosedur dan penalaran matematika untuk menyelesaikan permasalahan yang telah diformulasikan untuk memperoleh solusi matematis (Organisation for Economic Co-operation and Development, 2013). Jika dikaitkan dengan proses matematisasi dan pemodelan matematika (Blum, 2011; de Lange, 2006), maka kemampuan siswa Kalimantan Timur dalam menyelesaikan permasalahan dengan konsep, algoritma, atau rumus matematika tertentu tergolong rendah. Berikut soal matematika model PISA yang memuat proses employ sebagaimana disajikan pada Gambar 9.

Tema 1 "Membaca Buku" (Soal 1 s.d. 4)

Fajar membaca novel yang tebalnya 426 halaman. Pada hari pertama ia membaca 19 halaman dan pada hari-hari berikutnya ia membaca 3 halaman setiap hari.

Soal 2:

Dengan menunjukkan cara penyelesaiannya, tentukan berapa minggu yang Fajar perlukan untuk membaca novel tersebut hingga selesai?

\section{Gambar 9. Contoh Soal Model PISA Domain Proses Employ}

Soal pada Gambar 9 mengukur kemampuan siswa dalam mengestimasi suatu solusi permasalahan yang berkaitan dengan pola linier dalam kehidupan sehari-hari serta menunjukkan cara pengerjaannya. Siswa dapat menyelesaikannya dengan menggunakan konsep persamaan yang telah diperoleh pada soal sebelumnya atau dengan pendekatan yang lain. Namun, soal ini juga menekankan kemampuan unjuk kerja penyelesaiannya secara efektif sehingga cara pengerjaan siswa menjadi pertimbangan penskoran. Dengan demikian, kompetensi matematika yang digunakan adalah komunikasi dan matematisasi (Organisation for Economic Co-operation and Development, 2013). Contoh jawaban siswa yang tergolong benar (Gambar 10), sebagian benar (Gambar 11), dan salah (Gambar 12).

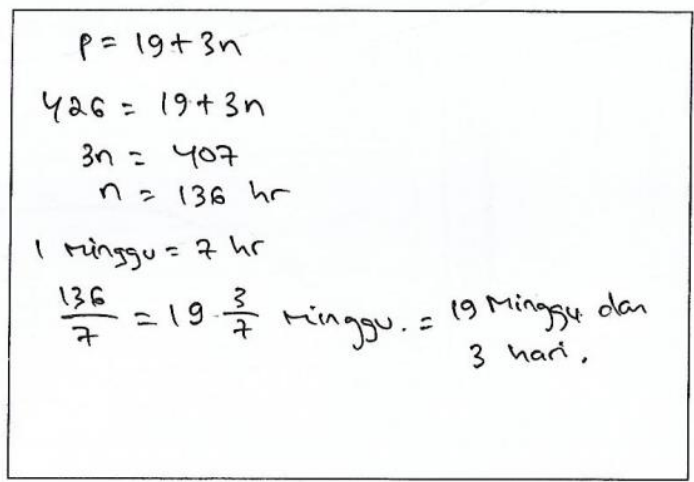

Gambar 10. Contoh Jawaban Benar Soal Model PISA Domain Proses Employ

Contoh jawaban siswa pada Gambar 10 menunjukkan bahwa siswa mampu menyelesaikan permasalahan berdasarkan konteks dan mengomunikasikan cara pengerjaannya.

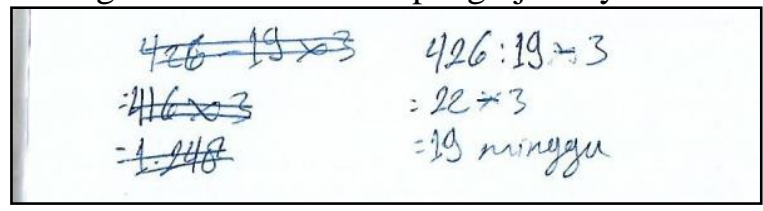

Gambar 11. Contoh Jawaban Sebagian Benar Soal Model PISA Domain Proses Employ

Contoh jawaban siswa pada Gambar 11 termasuk sebagian benar. Meskipun siswa memberikan solusi permasalahan yang hampir tepat, cara penyelesaian tidak dijelaskan dengan baik atau tidak tuntas. Hal ini menunjukkan bahwa kemampuan komunikasi matematika siswa tersebut rendah. 


$$
\begin{aligned}
P & =426-19+3 n \\
& =426-22 \\
& =124 \\
& =3 a d i 124 \text { Hari yg harus diperlukan } \\
& \text { untuk membaca novel hingga selesai. }
\end{aligned}
$$

\section{Gambar 12. Contoh Jawaban Salah Soal Model PISA Domain Proses Employ}

Contoh jawaban siswa pada Gambar 12 menunjukkan bahwa kemampuan matematisasi dan komunikasi matematis siswa rendah, yakni siswa tidak mampu menyelesaikan permasalahan berdasarkan konteks maupun mengomunikasikan cara pengerjaannya dengan baik. Persentase jawaban siswa untuk soal pada Gambar 9 disajikan pada Gambar 13.

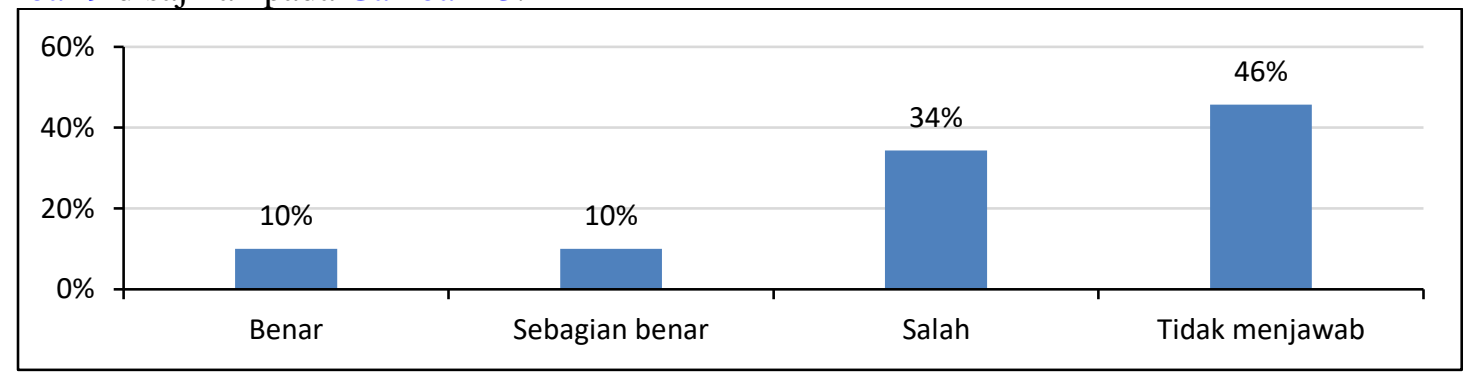

Gambar 13. Persentase Jawaban Siswa pada Contoh Soal Model PISA Domain Proses Employ

Rendahnya persentase siswa yang menjawab benar menunjukkan bahwa masih sedikit siswa Kalimantan Timur yang memiliki kemampuan matematisasi dan komunikasi pada proses employ. Namun persentase siswa yang tidak mengerjakan soal ini lebih tinggi lagi. Artinya, siswa Kalimantan Timur menganggap soal ini sulit dan merepotkan karena mengharuskan siswa untuk menunjukkan cara penyelesaiannya. Hal ini disebabkan karena bentuk penilaian akhir semester dan ujian nasional pada kurikulum Indonesia yang berupa pilihan ganda, sehingga siswa Indonesia lebih terbiasa mengerjakan soal pilihan ganda dan tidak biasa dalam menyelesaikan soal yang menuntut siswa untuk menunjukkan cara pengerjaannya.

Kemampuan siswa Kalimantan Timur pada proses interpret lebih rendah dari pada proses formulate dan employ, bahkan lebih rendah dari pada capaian siswa Indonesia yang menjadi sampel pada PISA 2012. Kemampuan proses interpret merupakan kemampuan siswa dalam merefleksi solusi, hasil, dan kesimpulan matematika serta menginterpretasikannya dalam permasalahan di kehidupan sehari-hari (Organisation for Economic Co-operation and Development, 2013). Jika dikaitkan dengan proses matematisasi dan pemodelan matematika (Blum, 2011; de Lange, 2006), maka kemampuan siswa Kalimantan Timur dalam menyelesaikan menginterpretasi, mengevaluasi dan mengomunikasikan solusi matematika terhadap konteks merupakan yang paling rendah. Berikut contoh soal matematika model PISA yang memuat proses interpret sebagai mana disajikan pada Gambar 14.

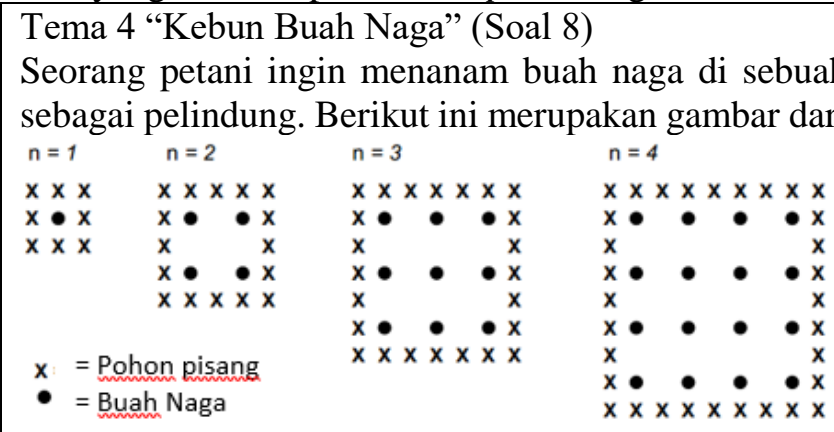

Soal 8:

Jika petani tersebut ingin memperluas kebun buah naganya, maka tanaman manakah yang banyaknya akan meningkat lebih cepat, buah naga atau pohon pisang? Jelaskan alasanmu 
Soal pada Gambar 14 mengukur kemampuan siswa dalam mengonstruk argumentasi dalam membandingkan peningkatan dua pola yang saling berhubungan pada situasi pekerjaan. Untuk menentukan tanaman yang peningkatan jumlahnya lebih tinggi, diperlukan kemampuan generalisasi pola dari permasalahan berdasarkan konteks, membandingkan dua representasi model matematika, dan mengonstruk argumentasi valid yang mendukung pilihan jawaban. Dengan demikian, kompetensi matematika yang digunakan adalah matematisasi, representasi dan komunikasi (Organisation for Economic Co-operation and Development, 2013). Contoh jawaban siswa yang tergolong benar (Gambar 15), sebagian benar (Gambar 16), dan salah (Gambar 17).

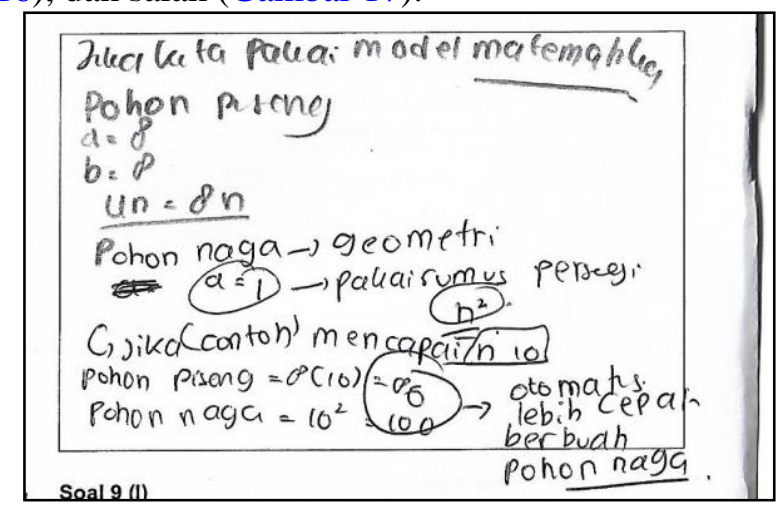

Gambar 15. Contoh Jawaban Benar Soal Model PISA Domain Proses Interpret

Contoh jawaban siswa pada Gambar 15 menunjukkan bahwa siswa mampu membuat generalisasi pola dan menyusun argumentasi jawaban dengan tepat.

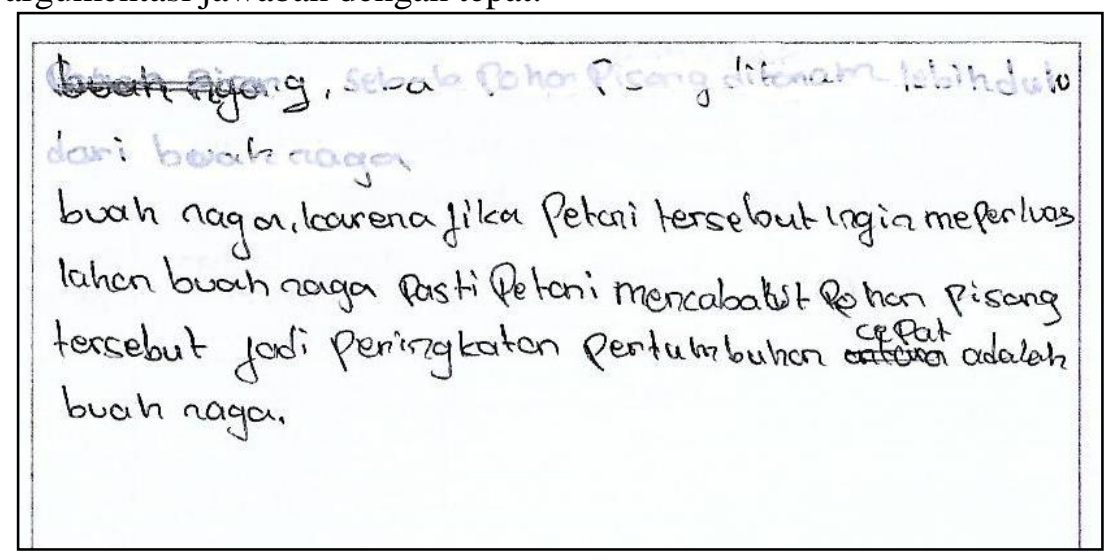

Gambar 16. Contoh Jawaban Sebagian Benar Soal Model PISA Domain Proses Interpret

Contoh jawaban siswa pada Gambar 16 termasuk sebagian benar. Meskipun memberikan pilihan yang tepat, siswa belum mampu mengomunikasikan argumentasi secara valid. Hal ini menunjukkan bahwa kemampuan komunikasi matematika siswa tersebut rendah.

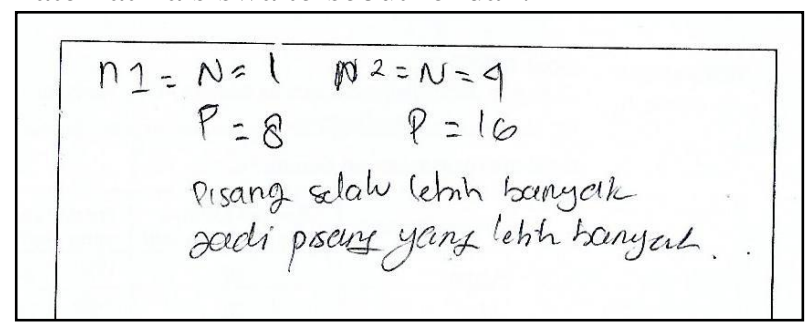

Gambar 17. Contoh Jawaban Salah Soal Model PISA Domain Proses Interpret

Contoh jawaban siswa pada Gambar 17 menunjukkan bahwa kemampuan matematisasi, representasi, dan komunikasi matematis siswa rendah, yakni siswa tidak mampu menggeneralisasi pola pada konteks permasalahan sehingga tidak dapat menentukan peningkatan jumlah tanaman dengan tepat. Persentase jawaban siswa untuk soal pada Gambar 14 disajikan pada Gambar 18. 


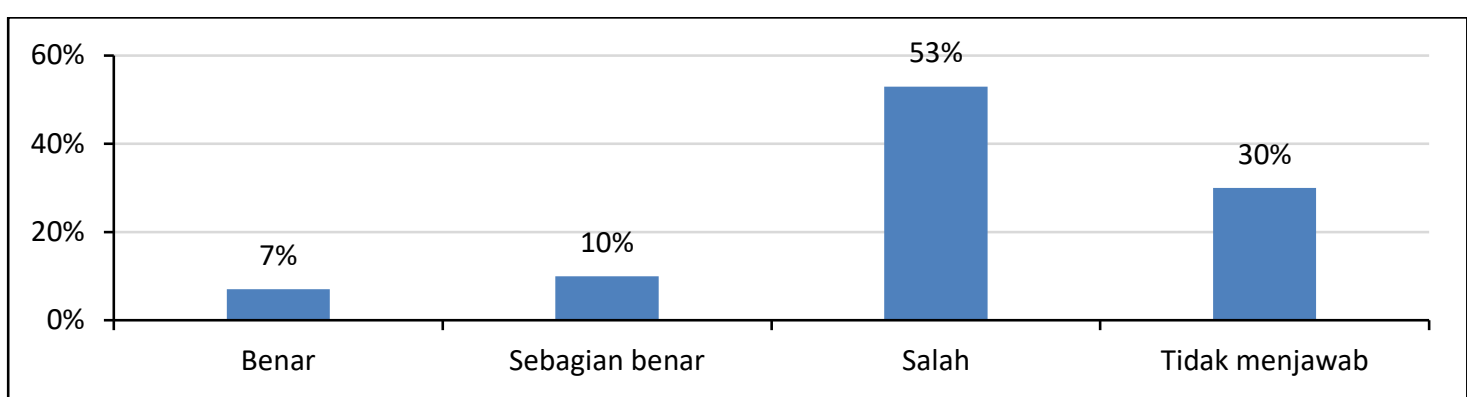

Gambar 18. Persentase Jawaban Siswa pada Contoh Soal Model PISA Domain Proses Interpret

Rendahnya persentase siswa yang menjawab benar dan sebagian benar menunjukkan bahwa masih sedikit siswa Kalimantan Timur yang memiliki kemampuan matematisasi, representasi dan komunikasi matematis pada proses interpret. Dengan kata lain, sebagian besar siswa Kalimantan Timur kesulitan dalam menyelesaikan soal yang memuat domain interpret.

Dengan demikian, kemampuan proses matematis siswa Kalimantan Timur tergolong rendah, yakni di bawah rata-rata negara OECD. Hal ini mirip dengan hasil penelitian Sari dan Wijaya (2017) terhadap siswa SMA DIY, yakni kemampuan proses matematis siswa SMA DIY pada setiap indikatornya tergolong rendah dan sangat rendah. Selain itu, kemampuan siswa Kalimantan Timur mengalami penurunan seiring domain proses matematis yang digunakan dalam menyelesaikan soal matematika model PISA. Hal ini ditunjukkan dengan skor siswa pada kemampuan pemodelan masalah kehidupan sehari-hari (formulate) hingga kemampuan menginterpretasikan solusi matematika ke dalam konteks permasalahan (interpret) yang menurun. Hal ini berbeda dengan dinamika kemampuan siswa Indonesia yang menjadi sampel PISA dan OECD, yakni kemampuan proses yang paling tinggi adalah kemampuan interpretasi solusi matematika dan yang paling rendah adalah kemampuan formulasi ke model matematika. Selain itu, dinamika kemampuan proses siswa Kalimantan Timur justru memiliki kesamaan dengan siswa di Shanghai, Hongkong, Macau, Korea, dan Singapura pada PISA 2012 (Organisation for Economic Co-operation and Development, 2014b). Hal ini menunjukkan bahwa siswa Indonesia di berbagai daerah memiliki kemampuan proses matematika yang beragam. Keragaman ini dapat dipengaruhi oleh berbagai faktor, diantaranya bentuk kurikulum yang yang diterapkan, kualitas dan praktik mengajar di kelas (Indartono \& Hamidy, 2019; Hamidy \& Jailani, 2018; Demir, 2018).

\section{SIMPULAN}

Berdasarkan hasil penelitian dan pembahasan, dapat disimpulkan bahwa kemampuan siswa Kalimantan Timur dalam menyelesaikan soal model PISA masih berada di bawah rata-rata negara OECD. Namun hasil tersebut lebih baik jika dibandingkan dengan capaian skor siswa Indonesia yang menjadi sampel pada PISA 2015. Kemampuan siswa Kalimantan Timur dalam menyelesaikan soal matematika model PISA secara umum masih berada pada level 1. Kemampuan tersebut lebih rendah dari pada standar OECD yang berada pada level 3, namun lebih baik jika dibandingkan dengan capaian siswa Indonesia yang menjadi sampel PISA 2000-2015. Kemampuan proses matematis siswa pada setiap indikatornya masih di bawah rata-rata Negara-negara OECD. Kemampuan proses matematis yang paling dikuasai oleh siswa yaitu proses formulate, diikuti kemampuan proses employ dan interpret. Sampel yang digunakan pada penelitian ini berbeda dengan sampel yang digunakan PISA untuk mengukur literasi matematika siswa Indonesia. Dengan demikian perbandingan kemampuan yang disajikan antara siswa Kalimantan Timur dan siswa Indonesia yang menjadi sampel PISA tidaklah sepenuhnya sepadan. Oleh karena itu, penelitian selanjutnya perlu menggunakan sampel yang lebih representatif, sehingga informasi yang diperoleh lebih akurat dan comparable dengan sampel yang diteliti oleh PISA di Indonesia. Selain itu, penelitian lainnya perlu dilakukan untuk menginvestigasi kemampuan siswa dalam menyelesaikan soal model PISA ditinjau dari aspek konten yang diujikan.

\section{DAFTAR PUSTAKA}

Afifah, I. R. N., \& Retnawati, H. (2019). Is it difficult to teach higher order thinking skills? Journal of Physics: Conference Series, 1320, 012098. https://doi.org/10.1088/1742-6596/1320/1/012098

Ahyan, S., Zulkardi, Z., \& Darmawijoyo, D. (2014). Developing mathematics problems based on pisa 


\section{Jurnal Riset Pendidikan Matematika, 6 (2), 2019 - 148}

Anwaril Hamidy, Jailani Jailani

level of change and relationships content. Journal on Mathematics Education, 5(1), 47-56. doi:https://doi.org/10.22342/jme.5.1.1448.47-56

Ary, D., Jacobs, L. C., Irvine, C. K. S., \& Walker, D. (2018). Introduction to research in education. Cengage Learning.

Badan Penelitian dan Pengembangan. (2011). Survei internasional PISA. Http://Litbang.Kemdikbud.Go.Id/; Kementerian Pendidikan dan Kebudayaan Republik Indonesia. http://litbang.kemdikbud.go.id/index.php/survei-internasional-pisa/tentang-pisa

Blum, W. (2011). Can modelling be taught and learnt? Some answers from empirical research. In Trends in Teaching and Learning of Mathematical Modelling (pp. 15-30). Springer. https://doi.org/10.1007/978-94-007-0910-2_3

Cohen, L., Manion, L., \& Morrison, K. (2007). Research methods in education (6th ed.). Routledge. https://doi.org/10.1080/19415257.2011.643130

de Lange, J. (2006). Mathematical literacy for living from OECD-PISA perspective. Tsukuba Journal of Educational Study in Mathematics, 25, 13-35. http://www.human.tsukuba.ac.jp/ mathedu/2503.pdf

Demir, S. B. (2018). The effect of teaching quality and teaching practices on PISA 2012 mathematics achievement of Turkish students. International Journal of Assessment Tools in Education, 5(4), 645-658. https://doi.org/10.21449/ijate.463409

Ebel, R. L., \& Frisbie, D. A. (1991). Essentials of educational measurement. Prentice Hall.

Gall, M. D., Gall, J. P., Borg, W. R. D., \& Gall, J. P. (2003). Educational research: An introduction (7th ed.). Pearson Education Inc.

Hamidy, A., \& Jailani, J. (2018). Factors influencing students' performance in solving international mathematics tests. Character Education for 21 st Century Global Citizens: Proceedings of the 2nd International Conference on Teacher Education and Professional Development (INCOTEPD 2017), October 21-22, 2017, Yogyakarta, Indonesia, 353-362.

Indartono, S., \& Hamidy, A. (2019). The contribution of test type and curriculum difference on the effect of the national test score at international mathematic test score: The challenge of IR 4.0 curriculum. Eurasian Journal of Educational Research, 19(82), 1-12. https://doi.org/10.14689/ejer.2019.82.10

Kaleli-Yılmaz, G., \& Hanci, A. (2016). Examination of the 8th grade students' TIMSS mathematics success in terms of different variables 1. International Journal of Mathematical Education in Science and Technology, 47(5), 674-695. https://doi.org/10.1080/0020739X.2015.1102977

National Council of Teacher Mathematics. (2000). Prinsiples and standards for school mathematics. NCTM.

Neumann, I., Duchhardt, C., Grüßing, M., Heinze, A., Knopp, E., \& Ehmke, T. (2013). Modeling and assessing mathematical competence over the lifespan. Journal for Educational Research Online/Journal Für Bildungsforschung Online, 5(2), 80-109. http://j-e-ro.com/index.php/jero/article/view/362

Novferma, N. (2016). Analisis kesulitan dan self-efficacy siswa SMP dalam pemecahan masalah matematika berbentuk soal cerita. Jurnal Riset Pendidikan Matematika, 3(1), 76-87. https://doi.org/http://dx.doi.org/10.21831/jrpm.v3i1.10403

Organisation for Economic Co-operation and Development. (2013). PISA 2012 assessment and analytical framework: Mathematics, reading, science, problem solving and financial literacy. OECD. https://doi.org/10.1787/9789264190511-en

Organisation for Economic Co-operation and Development. (2014a). PISA 2012 results: Creative problem solving: Students' skills in tackling real-life problems (Volume V). OECD, Paris, France.

Organisation for Economic Co-operation and Development. (2014b). PISA 2012 results: What students know and can do (Volume I, Revised edition, February 2014). OECD Publishing. https://doi.org/10.1787/9789264208780-en

Organisation for Economic Co-operation and Development. (2016). PISA 2015 results, excellence and equity in education. In Pisa: Vol. I. https://doi.org/10.1787/9789264266490-en 
Pusat Penelitian Pendidikan Kementerian Pendidikan dan Kebudayaan Republik Indonesia. (2018). Laporan hasil ujian nasional 2016/2017. https://hasilun.puspendik.kemdikbud.go.id/\#2017!smp!capaian_wilayah!16\&99\&999!T\&C\&1 $\& T \& 1 \& ! 2 ! \&$

Pusztai, G., \& Bacskai, K. (2015). Parochial schools and PISA effectiveness in three Central European Countries. Acta Universitatis Sapientiae. Social Analysis, 5(2), 145. http://www.acta.sapientia.ro/acta-social/C5-2/social52-03.pdf

Sáenz, C. (2009). The role of contextual, conceptual and procedural knowledge in activating mathematical competencies (PISA). Educational Studies in Mathematics, 71(2), 123-143. https://doi.org/10.1007/s10649-008-9167-8

Sari, R. H. N., \& Wijaya, A. (2017). Mathematical literacy of senior high school students in Yogyakarta. Jurnal Riset Pendidikan Matematika, 4(1), 100. https://doi.org/10.21831/jrpm.v4i1.10649

Setiawan, H., Dafik, D., \& Sri Lestari, N. (2014). Soal matematika dalam pisa kaitannya dengan literasi matematika dan kemampuan berpikir tingkat tinggi. Prosiding Seminar Matematika Dan Pendidikan Matematik, l(1). $\quad$ Retrieved from https://jurnal.unej.ac.id/index.php/psmp/article/view/955

Stacey, K. (2011). The PISA view of mathematical literacy in Indonesia. Journal on Mathematics Education, 2(2). https://doi.org/10.22342/jme.2.2.746.95-126

Tienken, C. (2014). PISA problems. AASA Journal of Scholarship and Practice, 10(4), 4-18.

Umbara, U., \& Suryadi, D. (2019). Re-interpretation of mathematical literacy based on the teacher's perspective. International Journal of Instruction, 12(4), 789-806. https://doi.org/10.29333/iji.2019.12450a

Van Dooren, W., De Bock, D., Vleugels, K., \& Verschaffel, L. (2011). Word problem classification: A promising modelling task at the elementary level. In G. Kaiser, W. Blum, R. Borromeo Ferri, \& G. Stillman (Eds.), Trends in Teaching and Learning of Mathematical Modelling (pp. 47-55). Springer. https://doi.org/10.1007/978-94-007-0910-2_6

Wardhani, S., \& Rumiati, R. (2011). Instrumen penilaian hasil belajar matematika SMP: Belajar dari PISA dan TIMSS. http://p4tkmatematika.org/file/Bermutu 2011/SMP/4.INSTRUMEN PENILAIAN HASIL BELAJAR MATEMATIKA .....pdf

Wijaya, A., van den Heuvel-Panhuizen, M., Doorman, M., \& Robitzsch, A. (2014). Difficulties in solving context-based PISA mathematics tasks: An analysis of students' errors. The Mathematics Enthusiast, 11(3). http://scholarworks.umt.edu/tme/vol11/iss3/8

Wulandari, N. F. (2015). Kemampuan matematika siswa SMP dan SMA di daerah istimewa Yogyakarta dalam menyelesaikan soal model TIMSS dan PISA. Universitas Negeri Yogyakarta.

Wulandari, N. F., \& Jailani, J. (2015). Indonesian students' mathematics problem solving skill in PISA and TIMSS. Proceeding of International Conference On Research, Implementation And Education Of Mathematics and Sciences 2015 (ICRIEMS 2015). 